\begin{tabular}{l}
\hline Jurnal Scripta Teologi dan Pelayanan Kontekstual \\
ISSN 2086-5368 (Print) \\
ISSN \\
Http://ejournal.stte.ac.id \\
Vol.3, No.1, pp. 75-98, 2018
\end{tabular}

\title{
Pentingnya Integritas Pelayan Kristus Menurut Titus 1: 6-9 Dalam Upaya Peningkatan Pelayanan Gerejawi
}

\author{
Suharta \\ STT Ebenhaezer Tanjung Enim, Imsuharta.te@gmail.com
}

\begin{tabular}{l} 
INFO ARTIKEL \\
\hline Sejarah Artikel: \\
Diterima : 03 Mei 2018 \\
Direvisi : 10 Mei 2018 \\
Disetujui: 19 Mei 2018 \\
Dipublikasi: 28 Mei \\
2018
\end{tabular}

Kata Kunci:

Pentingnya, Integritas,

Pelayan, Peningkatan,

Gerejawi.

Keywords:

keyword one, keyword two, keyword three.

\section{ABSTRAK}

Kehidupan yang berintegritas adalah kehidupan yang menjadikan Kristus sebagai pusat segala sesuatu, pikiran yang difokuskan untuk melakukan apa yang Tuhan pikirkan dan suatu tindakan yang mengarah kepada suatu perubahan yang positif. Kehidupan yang berintegritas berbicara tentang keutuhan, kejujuran, kesatuan, antara apa yang diucapkan dan dilakukan oleh seseorang dengan tanggung jawab, kehidupan yang dikehendaki oleh Allah untuk setiap individu Kristen. Secara khusus jika orang tersebut adalah seorang Pelayan Kristus haruslah mempunyai integritas di dalam dirinya sendiri karena integritas menjadi kunci bagi seorang pemimpin. Kehidupan yang demikian dapat dibangun dengan hati yang penuh dengan belaskasihan dan tulus, pikiran yang tertuju kepada perkara-perkara yang Tuhan kehendaki, dan sesuai dengan perbuatan atau tindakan yang dimulai dari dalam diri sendiri. Oleh karena itu, integritas menjadi sesuatu yang sangat penting, manakala diperhadapkan pada situasi zaman yang semakin buruk. Lebih-lebih jika soal integritas ini dihubungkan dengan persoalan kepercayaan dan dukungan yang berkaitan dengan pelayanan gerejawi.

\footnotetext{
ABSTRACT

A life of integrity is a life that makes Christ the center of all things, a mind focused on doing what God thinks and an action that leads to a positive change. A life of integrity speaks of wholeness, honesty, unity, between what someone says and does with responsibility, the life God wants for every Christian individual. Specifically if the person is a Servant of Christ must have integrity in himself because integrity is the key to a leader. Such a life can be built with a heart full of mercy and sincerity, a mind directed to the things that God wants, and in accordance with actions or actions that start from within oneself. Therefore, integrity becomes something very important, when faced with a situation that is getting worse. The more so if the issue of integrity is linked to issues of trust and support related to ecclesiastical services.
} 


\section{Pendahuluan}

Integrity atau integritas adalah suatu konsep yang menunjuk konsistensi antara tindakan dengan nilai dan prinsip. Seorang yang berintegritas ditandai oleh satunya kata dan perbuatan bukan seorang yang kata-katanya tidak dapat dipertanggungjawabkan. Seorang yang mempunyai integritas bukan tipe manusia dengan banyak wajah dan penampilan yang disesuaikan dengan motif dan kepentingan pribadinya.

Pada dasarnya aspek yang paling penting dari kehidupan sebagai orang Kristen yaitu bagaimana menjadi orang yang berintegritas. Secara khusus jika orang tersebut adalah seorang Pelayan Kristus haruslah mempunyai integritas di dalam dirinya sendiri karena integritas menjadi kunci bagi seorang pemimpin. Kehidupan yang berintegritas adalah kehidupan yang memiliki hubungan dengan banyak hal, karena memang setiap manusia diciptakan untuk memiliki tiga dimensi hubungan. Ketiga hubungan itu ialah hubungan dengan dirinya sendiri, hubungan dengan orang lain dan hubungan dengan Allah. ketiganya dapat dibedakan tetapi hubungan ini tidak dapat dipisahkan dalam kehidupan Kristen. Paulus merupakan salah satu contoh pribadi yang memiliki kehidupan yang handal dan dapat menjadi agen pengubah, yang beriman dan berani mengambil resiko.

Hal ini menunjukan bahwa kehidupan yang berintegritas adalah kehidupan yang menjadikan Kristus sebagai pusat segala sesuatu, pikiran yang difokuskan untuk melakukan apa yang Tuhan pikirkan dan suatu tindakan yang mengarah kepada suatu perubahan yang positif yang disebut oleh Jhon Wesley sebagai kesempurnaan Kristen. Dengan demikian kehidupan yang berintegritas berbicara tentang keutuhan, kejujuran, kesatuan, antara apa yang diucapkan dan dilakukan oleh seseorang dengan tanggung jawab, kehidupan yang dikehendaki oleh Allah untuk setiap individu Kristen. Kehidupan yang dibangun dengan hati yang penuh dengan belaskasihan dan tulus, pikiran yang tertuju kepada perkara-perkara yang Tuhan kehendaki, dan perbuatan atau tindakan yang dimulai dari dalam diri sendiri dan tindakan yang diadaptasikan sesuai dengan adat setempat dimana ia berada.

Namun pada kenyataannya Tuhan Yesus dalam pemberitaan Injil Kerajaan Allah mengalami banyak tantangan tidak hanya dari kalangan rendah tetapi juga dari kalangan atas yang menyebut dirinya ahli taurat, orang farisi, orang saduki dan para pemimpin agama Yahudi. Tuhan Yesus menyebut mereka orang munafik orang yang hidup dalam kebutaan yang menuntun orang dalam kebutaan, yang tidak segan-segan melakukan korupsi, kolusi dan nepotisme. Pada kenyataannya juga bahwa banyak orang yang hidupnya tidak memuliakan Tuhan dan itu tampak pada saat Tuhan melayani orang Yahudi.

Hal itu juga sedang terjadi dalam kehidupan kristen, maka sangat disayangkan bahwa pada saat ini ternyata kehidupan Kristen banyak yang tidak lagi memiliki integritas diri, standart pribadi seseorang begitu gampang runtuh hanya karena uang, jabatan dan wanita, hal ini juga yang membuat hidup orang percaya seperti "Bunglon" yang tidak memiliki pendirian. Oleh karena itu, integritas menjadi sesuatu yang sangat penting, manakala diperhadapkan pada situasi zaman yang semakin buruk. Lebih-lebih jika soal integritas ini dihubungkan dengan persoalan kepercayaan dan dukungan yang berkaitan dengan para pemimpin. Integritas menjadi sangat penting oleh karena integritas menjadi karakter kunci bagi seorang pemimpin. Seorang pemimpin yang mempunyai integritas akan mendapatkan 
kepercayaan (trust) dari pegawainya. Pimpinan yang berintegritas dipercayai karena apa yang menjadi ucapannya juga menjadi tindakannya.

\section{Latar Belakang Penulisan Surat Titus}

Surat ini dialamatkan kepada Titus. Titus adalah seorang Yahudi dan sahabat Paulus (Titus 1: 4). Dikatakan bahwa Titus adalah anak Paulus yang sah menurut iman mereka bersama. Ada kemungkinan besar bahwa ini berarti Titus bertobat melalui pelayanan Paulus. Hal ini terjadi sebelum sidang di Yerusalem (Kisah Para Rasul 15), karena menurut Galatia 2: 1 dan seterusnya maka Titus ikut serta dalam sidang tersebut. Menurut beberapa penafsir maka Titus adalah anggota jemaat di Antiokhia. Bahwa dia tidak bersunat menunjukkan bahwa dia berlatar belakang agama kafir

Perlu dicatat bahwa Titus tidak disebut dalam Kisah Para Rasul. Itu tidak berarti dia kurang aktif dalam pelayanan. Sebaliknya, dalam surat-surat Korintus dilaporkan bahwa Paulus dua kali mengutus Titus ke Korintus (2 Kor. 7: 6 dst., 8: 16 dst., 12: 18). Jelaslah bahwa dia sangat setia dan tidak mementingkan dirinya sendiri. Ia sehati dengan Paulus dan memang Paulus menaruh kepercayaan kepadanya. Perlu diperhatikan juga bahwa Titus menyertai Paulus pada waktu Paulus dipenjarakan di Roma untuk pertama kali. Setelah Paulus dilepaskan, mereka berdua mengadakan perjalanan antara lain ke pulau Kreta. Karena Paulus mengurus banyak jemaat dan dia ingin mengunjungi sebanyak mungkin tempat, maka dia sendiri tidak dapat tinggal lama di sana. Jadi, Paulus meninggalkan Titus supaya dia menyempurnakan pekerjaan yang ditinggalkan "dengan maksud ini, supaya dia mengatur apa yang masih perlu diatur dan supaya dia menetapkan penatua-penatua di setiap kota" (1:5).

\section{Tujuan Dan Maksud Penulisan}

Titus adalah seorang bukan Yahudi yang sudah masuk agama Kristen lalu menjadi teman sekerja dan pembantu Paulus dalam pekerjaannya. Surat ini ditujukan kepada Titus yang pada waktu itu berada di Kreta karena telah ditinggalkan di sana oleh Paulus untuk mengurus jemaat di sana.

Ada tiga hal yang dikemukakan di dalam surat ini: Pertama, Titus diingatkan mengenai sifat-sifat orang yang boleh menjadi pemimpin jemaat. Hal itu dikemukakan terutama karena kelakuan orang-orang di Kreta banyak yang jahat. Kedua, Titus dinasihati mengenai bagaimana seharusnya ia mengajar setiap golongan orang yang menjadi anggota jemaat itu, yaitu golongan laki-laki dan wanita yang sudah tua (yang seharusnya mengajar pula orang-orang yang lebih muda dari mereka), golongan orang-orang muda, dan golongan hamba-hamba. Akhirnya Titus diajar mengenai bagaimana seharusnya kelakuan orang Kristen. Yang paling penting ialah bahwa orang Kristen harus peramah dan suka damai, jangan membenci orang, jangan suka bertengkar atau menimbulkan perpecahan.

Surat ini ditulis sebagai dukungan kepada Titus untuk terus mengajarkan iman yang benar dan membimbing jemaat agar tetap hidup sesuai dengan kehendak Allah. Sejumlah orang dalam jemaat-jemaat di Kreta rupanya berusaha menyesatkan anggota lainnya dengan ajaran-ajaran sesat (1:10-14; 3: 9-10). Surat kepada Titus juga memuat petunjuk dan nasihat bagi para pemimpin jemaat dan bagi seluruh jemaat Allah.

\section{Konteks Penulisan Surat Titus}


Titus 1: 1-4 ini merupakan salam yang diberikan Paulus kepada anaknya yang sah menurut iman bersama: kasih karunia dan damai sejahtera dari Allah Bapa dan Kristus Yesus. Titus 1: 1-4 ini merupakan kesadaran Paulus mengenai panggilannya yang mulia. Oleh karena itu, Paulus memberi tugas kepada Titus yang pada waktu itu berada di Kreta. Kreta ialah satu pulau di Laut Tengah, yang sebagian besar berbukit-bukit. Dalam Perjanjian Lama tidak disebut dengan namanya, tapi barangkali orang-orang Kreti, yang membentuk sebagian dari pasukan pengawal pribadi Daud. Dalam Perjanjian Baru orang-orang Kreta disebut di antara mereka yang hadir pada hari pentakosta (Kis 2: 11) dan kemudian pulau Kreta disebut dalam laporan mengenai perjalanan Paulus ke Roma (Kis 27: 7-13, 21).

Paulus meninggalkan Titus di Kreta untuk melanjutkan pekerjaan memelihara iman orang-orang pilihan Allah, pengetahuan akan kebenaran dalam ibadah, berpengharapan akan hidup yang kekal kepada Allah dan memberitakan Injil yang telah dipercayakan sesuai dengan perintah Allah, Juruselamat. Tujuan penulisan ini adalah untuk mengatur apa yang masih perlu diatur dan menetapkan penatua-penatua dan penilik jemaat di setiap kota (Ay. $5)$.

Paulus telah meninggalkan Titus di Kreta untuk meneruskan pendirian pekerjaan pekabaran Injil di sana, teristimewa untuk mengamati pemilihan penatua-penatua di tiaptiap jemaat setempat (band. Kis 14: 23). Dia bukan hanya menugasi Titus untuk pekerjaan demikian, tetapi dia juga menunjukkan bagaimana Titus harus melakukannya dengan baik melalui penunjukan orang yang bagaimana untuk diangkat. Petunjuk-petunjuk ini dia ulangi dan tekankan sekarang. Setiap orang yang hendak diangkat, haruslah tidak bercela baik mengenai sifat maupun kelakuan, bebas dari kelemahan moral yang tidak wajar, aktif dalam pekerjaan-pekerjaan yang baik dan berupaya mengejar kesalehan pribadi. Dengan tak menyimpang dari kesetiaannya terhadap kebenaran yang diterimanya, dia dapat memberi semangat kepada banyak orang, dengan pengajarannya yang sehat dan membesarkan kesalahan setiap orang yang mengajarkan hal yang bertentangan dengan kebenaran itu.

\section{Analisa Eksegetis Dan Uraian Titus 1: 6-9}

\section{Tidak Bercacat $(6 a, 7)$}

Kata "tidak bercacat" dalam teks ini dituliskan dengan kata à $\nu ' \gamma \kappa \lambda \eta \tau o \varsigma$ dalam bentuk adjective normal nominative masculine singular no degree from $\alpha^{\prime} \nu^{\prime} \gamma \kappa \lambda \eta \eta \tau \varsigma$ yang artinya yang tak bercela. ${ }^{1}$ Dalam terjemahan NIV menggunakan kata blameless yang artinya tidak bersalah. ${ }^{2}$ Sedangkan dalam terjemahan NAS menggunakan kata above reproach yang artinya tidak dapat dicela. ${ }^{3}$ Barclay menterjemahkan $\alpha^{\alpha} \nu^{\prime} \gamma \kappa \kappa \lambda \eta \tau \varsigma$ yakni tidak bercacat. ${ }^{4}$ Sedangkan dalam Oxford diterjemahkan tidak bersalah. ${ }^{5}$

\footnotetext{
${ }^{1}$ Hasan Sutanto, Perjanjian Baru Interlinier dan Konkordansi Perjanjian Baru I, (Jakarta: LAI, 2003), 1141

${ }^{2}$ Kenneth Barker, The NIV Study Bible, (Michigan: Zondervan Publishing House, 1985), 1851 1977), 1402

${ }^{3}$ Spiros Zodhiates, The Hebrew-Greek Key Study Bible, (La Habra: The Lockman Foundation,

${ }^{4}$ Barclay M. Newman Jr, Kamus Yunani-Indonesia, (Jakarta: BPK Gunung Mulia, 1991), 12

${ }^{5}$ Joyce M. Hawkins, Oxford-Erlangga Kamus Dwibahasa, (Jakarta: Erlangga, 1999), 25
} 
Kamus Besar Bahasa Indonesia menterjemahkan "tidak bercacat" yakni tidak kekurangan yang menyebabkan nilai atau mutunya kurang baik atau kurang sempurna (yang terdapat pada badan, benda, batin, akhlak). ${ }^{6}$

Persyaratan bagi pemimpin gereja tampaknya tidak berbeda dari yang dapat diharapkan dari seorang pejabat negara yang baik: seseorang yang memiliki sifat yang baik, berpengalaman, kejujuran. Hidupnya yang baik menjadi pendukung bagi nasihat-nasihat yang baik. Singkatnya, ia hendaknya seorang tokoh publik yang mengerti tanggung jawab. ${ }^{7}$

Ketika menguraikan ayat yang berisi persyaratan gembala sidang di surat 1 Timotius, yang berbicara tentang perkawinan, tetapi perhatikan perintah yang lebih tegas tentang anakanak di Kreta. Petunjuk itu mencerminkan sistem keluarga di Kreta yang lebih ketat, di mana para orang tua lebih dipersalahkan karena tingkah laku anak-anaknya, atau menunjuk bahwa gereja yang didirikan di Efesus adalah lebih kuat. ${ }^{8}$

Jadi, kata "tidak bercacat" lebih menekankan kepada sifat atau watak yang dimiliki seseorang dalam bidang etis. Dalam 1 Timotius 3:2, 10 sangat jelas disebutkan bahwa hanya memiliki satu isteri, dapat menahan diri, bijaksana, sopan, bukan seorang peminum, bukan pemarah, pendamai dan bukan hamba uang. Dapat membina keluarga dan anak-anaknya hidup beriman dan tidak dapat dituduh karena hidup tidak senonoh atau hidup tidak tertib. Bila seseorang tidak dapat membina anak-anaknya, ia juga tidak dapat membina jemaat Tuhan. Sehingga ketika seseorang dipilih menjadi seorang penatua dalam jemaat tidak dapat dipersalahkan oleh apapun dan menjadi teladan dalam sikap hidup.

Setelah diuraikan dengan jelas tentang tidak bercacat diatas, maka dapat disimpulkan bahwa yang dilakukan Titus untuk menetapkan penatua di setiap kota itu diperintahkan oleh rasul sendiri dengan mengindahkan syarat-syarat yang ditentukan Paulus bagi para penatua.

\section{Hidup Beriman (6b)}

Kata "hidup beriman" dalam teks ini ditulis dengan kata $\pi \iota \sigma \tau \alpha$ dalam bentuk adjective normal accusative neuter plural no degree from $\pi \iota \sigma \tau o ́ \varsigma$ yang artinya yang percaya. ${ }^{9}$ Dalam terjemahan NIV menggunakan kata believe yang artinya percaya. ${ }^{10}$ Sedangkan dalam terjemahan NAS menggunakan kata faithful yang artinya setia. ${ }^{11}$ Barclay menterjemahkan

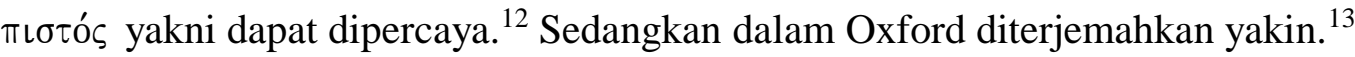

Kata "iman" ialah sikap yang di dalamnya seseorang melepaskan andalan pada segala usahanya sendiri untuk mendapatkan keselamatan, baik itu kebajikan, kebaikan susila atau apa saja, kemudian sepenuhnya mengandalkan Yesus Kristus dan mengharap hanya dari Dia segala sesuatu yang dimaksud oleh keselamatan. ${ }^{14}$

\footnotetext{
${ }^{6}$ Ali Lukman, Kamus Besar Bahasa Indonesia, (Jakarta: Balai Pustaka, 1991), 164

${ }^{7}$ Dianne bergant dan Robert J. karris, Tafsir Alkitab PB, (Yogyakarta: KANISIUS, 2002), 405

${ }^{8}$ E. M. Blaiklock, Surat-surat Penggembalaan, (Malang: Gandum Mas, 1981), 71

${ }^{9}$ Hasan Sutanto, Perjanjian Baru Interlinier..., 1141

${ }^{10}$ Kenneth Barker, The NIV Study Bible..., 1851

${ }^{11}$ Spiros Zodhiates, The Hebrew-Greek Key Study Bible..., 1402

${ }^{12}$ Barclay M. Newman Jr, Kamus Yunani-Indonesia..., 134

${ }^{13}$ Joyce M. Hawkins, Oxford-Erlangga Kamus Dwibahasa..., 22

14 J. D Douglas, Ensiklopedi Alkitab Masa Kini Jilid I, (Jakarta: Yayasan Komunikasi Bina Kasih, 2008), 431
} 
Jhon R. Tan dalam bukunya yang berjudul "Dinamika Pertumbuhan Iman Kristen" mengatakan iman yang sesungguhnya tidak terlepas dari pikiran yang kembali kepada Firman Tuhan, perasaan (hati) yang kembali kepada Kristus di Kalvari, pengharapan yang teguh menantikan kedatangan Kristus kedua kali dan keinginan (kemauan) yang kembali kepada kehendak Allah. ${ }^{15}$

Selain itu, Paulus menekankan prinsip bahwa tidak semua orang dapat dipilih untuk menduduki jabatan-jabatan dalam jemaat. Dalam memilih orang untuk jabatan-jabatan dalam jemaat, Paulus mengutamakan kualitas rohani calon hamba Tuhan dan bukan kepintarannya. ${ }^{16}$ Secara khusus harus memiliki iman yang kuat di dalam mengikut Tuhan.

Jadi, kata "hidup beriman" yang dimaksud di sini lebih menekankan kepada kesetiaan dan keyakinan seseorang kepada satu pribadi yang mereka kenal di dalam anak-Nya Yesus Kristus. Titus adalah alat yang dipakai oleh hambanya Paulus untuk menjalankan tugas penggembalaan bagi orang-orang yang di Kreta pada waktu itu untuk kuat di dalam mengikut Tuhan jangan tergoyahkan dengan ajaran-ajaran sinkretisme yang menyesatkan pada waktu itu.

\section{Menjadi Berkat (8)}

Kata "menjadi berkat" dalam teks ini ditulis dengan kata $\phi \iota \lambda o^{\prime} \xi \in \nu 0 \nu$ dalam bentuk adjective accusative masculine singular no degree from $\phi \iota \lambda \operatorname{co}_{\epsilon} \in \nu \varsigma$ yang artinya yang suka memberi tumpangan. ${ }^{17}$ Dalam terjemahan NIV menggunakan kata hospitable yang artinya ramah. ${ }^{18}$ Sedangkan dalam terjemahan NAS menggunakan kata hospitable yang artinya penuh kasih dari orang yang tak di kenal. ${ }^{19}$ Barclay menterjemahkan $\phi \iota \lambda o ́ \xi \epsilon \nu \circ \varsigma$ yakni ramahtamah. ${ }^{20}$ Sedangkan dalam Oxford diterjemahkan pelayanan yang baik. ${ }^{21}$

Kata berkat diartikan sebagai salah satu kata-kata pujian bagi Allah, atau kata-kata yang digunakan untuk membuat seseorang atau sesuatu menjadi kudus. Dalam Perjanjian Baru adalah semua karunia yang dijanjikan oleh Allah kepada manusia melalui Kristus (Kis 3: 25) dan karunia-karunia Kristus kepada para murid-Nya. ${ }^{22}$

Jadi, kata menjadi berkat yang dimaksudkan Titus ini adalah seorang yang memiliki sifat-sifat yang positif berlawanan dengan sifat-sifat negatip yang disebut di ayat 7 . Kepribadian yang penuh kasih, ramah tamah, suka memberi, memiliki pelayanan yang baik, dapat membangun dan memotivasi sesamanya di dalam melayani Tuhan.

\section{Berpegang Pada Ajaran Yang Benar (9)}

Kata "berpegang pada ajaran yang benar" dalam teks ini ditulis dengan kata

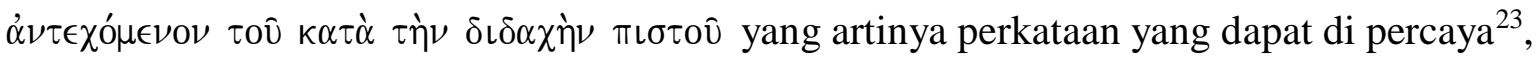
yaitu Injil yang murni (ada juga Injil yang telah dipalsukan oleh guru-guru sesat). Injil itu

15 John R. Tan, Dinamika Pertumbuhan Iman Kristen, (Jakarta: Yasinta, 2006), 17

${ }^{16}$ Ola Tulluan, Introduksi Perjanjian Baru, (Batu: YPPII, 1999), 237

${ }^{17}$ Sutanto, Perjanjian Baru Interlinier..., 1141

${ }^{18}$ Barker, The NIV Study Bible..., 1851

${ }^{19}$ Zodhiates, The Hebrew-Greek Key Study Bible..., 1402

${ }^{20}$ Newman Jr, Kamus Yunani-Indonesia..., 184

${ }^{21}$ Hawkins, Oxford-Erlangga Kamus Dwibahasa..., 135

${ }^{22}$ W. R. F. Browning, Kamus Alkitab, (Jakarta: Gunung Mulia, 2011), 56-57

${ }^{23}$ Sutanto, Perjanjian Baru Interlinier..., 1141 
hanya dapat dikatakan murni, kalau ia sesuai dengan ajaran yang sehat, yaitu ajaran rasuli. Injil yang diberitakan dan diajarkan Paulus dapat disebut ajaran yang sehat, karena menjadikan hidup manusia yang rusak karena dosa, sehat kembali. Injil keselamatan Kristus membawa manusia kepada pembaharuan hidup, yang menentang dosa-dosa.

Hanya bila penatua itu berpegang pada ajaran yang sehat, ia akan sanggup menasihati orang, yaitu baik dalam hal iman maupun dalam hal kelakuan hidup. Ia akan pula sanggup meyakinkan penentang-penentangnya, yaitu para penganut ajaran sesat (ay. 10), sehingga mereka sadar dengan keadaan mereka. Dari ayat ini kita melihat betapa pentingnya Paulus anggap ajaran yang murni bagi tugas pembinaan jemaat di bidang iman maupun kelakuan hidup. Oleh sebab itu, tugas seorang penatua adalah di samping memerintah jemaat, mengajar dan menasihati, juga menjaga kemurnian ajaran di dalam jemaat. ${ }^{24}$

Jadi, kata "berpegang pada ajaran yang benar" sangat jelas dan tegas dinyatakan oleh Paulus supaya berpegang kuat-kuat pada ajaran yang benar, dan sebagai akibatnya, menolak ajaran yang salah. Tingkah laku dikaitkan dengan iman yang teguh. Kepercayaan adalah persoalan yang sangat penting yang dihadapi orang percaya pada zaman ini.

Kehidupan yang berintegritas (selaras antara yang diucapkan dan dilakukan), berbelas kasih (tidak suka menghakimi dan berbelas rasa), dan otentik (bersikap sewajarnya atau tidak munafik) merupakan kesaksian yang baik dan menarik. Kesaksian orang Kristen yang terkuat adalah kesaksian yang diucapkan oleh seorang percaya yang kehidupannya sesuai dengan Firman Tuhan (integritas). Seorang pelayan Kristus harus memiliki integritas dalam menjalani kehidupan sehari-hari sebagai saksi Kristus. Untuk memiliki integritas tersebut maka seorang pelayan harus sudah lahir baru, memiliki intimasi dengan Tuhan, memiliki kepribadian yang baik dan memiliki prinsip hidup dalam pelayanan.

Dengan memiliki integritas, maka para pelayan Tuhan telah menjadi kesaksian bagi orang-orang yang belum percaya kepada Kristus Yesus. Sikap hidup seorang saksi Kristus menjadi tolak ukur orang lain untuk menilai bedanya kehidupan seseorang yang telah mengenal Kristus Yesus dengan orang yang belum mengenal Kristus Yesus.

\section{Problematika Integritas Pelayan Kristus}

\section{Tidak Memiliki Panggilan Yang Jelas}

Panggilan adalah hal yang mendasar bagi pelayan Tuhan. Seseorang yang memiliki panggilan yang jelas untuk melayani Tuhan, maka harus menganggap bahwa melayani Tuhan lebih baik, meskipun di tengah-tengah penderitaan. Yap Un Han dalam bukunya mengatakan:

Orang yang menerima panggilan Tuhan, harus menganggap bahwa memilih pekerjaan Tuhan adalah yang terbaik. Bagaimanapun orang lain mencemooh atau berpendapat, hal ini tidak menghalanginya untuk menerima panggilan Tuhan. Disebut tugas baik bukan karena tugas ini dapat mencukupi kebutuhan orang lain, tetapi semata-mata karena panggilan Tuhan.

Dengan demikian dapat dikatakan bahwa orang yang memiliki panggilan yang jelas akan bersedia menanggung resiko dari setiap pelayanan, sebab jika tidak demikian maka akan dapat menimbulkan masalah serta dapat menghancurkan pelayanan.

${ }^{24}$ R. Budiman, Surat-surat Pastoral, (Jakarta: Gunung Mulia, 1989), 9 \& 131 
Dalam Matius 9: 37-38, Yesus berkata: "Tuaian memang banyak, tetapi pekerja sedikit. Karena itu mintalah kepada tuan yang empunya tuaian, supaya Ia mengirimkan pekerja-pekerja untuk tuaian itu." Disinilah letak panggilan itu. Panggilan Allah bukanlah untuk orang yang menyandang garis keturunan, talenta, gender atau status sosial yang istimewa. Panggilan-Nya diperuntukkan bagi semua orang yang mau menanggapinya dan bersamaan dengan panggilan itu akan diberikan Allah anugerah dan pengurapan. Tuhan memanggil setiap orang dan urapan-Nya yang akan memberikan kemampuan untuk menjawab panggilan itu. Tommy Tenney dalam bukunya menjelaskan mengenai panggilan bagi seseorang yaitu:

Allah Bapa pergi ke "jalan-jalan kecil" karena Ia sering mendapatkan rumah yang penuh dengan Marta yang beranggapan bahwa adalah tugas Maria-Maria untuk mengerjakan semua hal tentang "berdoa dan hal-hal kerohanian lainnya". Masalahnya disini adalah bahwa tidak ada yang mau "pergi ke luar" dari dapur yang nyaman di rumah Allah untuk bekerja di lapangan.

Pernyataan ini ironis sekali karena seakan-akan Tuhan kekurangan tangan-tangan di lapangan sehingga Ia memerintahkan umat-Nya untuk berdoa kepada Tuhan yang empunya tuaian untuk mengirimkan pekerja-pekerja bagi tuaian jiwa itu.

Berdasarkan hasil wawancara dengan $\mathrm{AB}$, ia mengatakan bahwa ia mengerti arti pelayanan. Tetapi, Panggilan melayani sebagai pelayan Kristus belum dimengerti dengan jelas. Demikian juga dikatakan oleh LB, yang mengatakan bahwa ia mengetahui panggilan melayani itu dari Tuhan tetapi hanya sebatas mengetahui tidak ada tindakan yang dilakukan.

\section{Tidak Memiliki Motivasi Yang Benar Dalam Melayani}

Secara umum, motivasi dapat didefinisikan sebagai segala sesuatu yang menyebabkan gerakan yang mendorong seseorang untuk bertindak, ${ }^{25}$ artinya bahwa, tidak ada tindakan atau gerakan yang terjadi tanpa didorong atau dipacu oleh motivasi. Seseorang yang melayani Tuhan dengan sungguh-sungguh akan memiliki motivasi yang benar dalam melayani. Motivasi tersebut timbul dari hati dan tentunya dengan tujuan untuk menyenangkan hati Tuhan.

Donald Whitney dalam bukunya "10 Pilar Penopang Kehidupan Kristen" menuliskan beberapa motif yang sangat penting dimiliki dalam melaksanakan pelayanan bagi Tuhan, antara lain yakni ${ }^{26}$ :

1. Tergerak oleh keinginan mau patuh

2. Tergerak oleh perasaan berterima kasih

3. Tergerak oleh sukacita

4. Digerakkan oleh fakta sudah diampuni

5. Digerakkan oleh kerendahan hati

6. Digerakkan oleh kasih

Oleh karena itu, setiap orang pasti memiliki motivasi atau tujuan masing-masing dalam melayani, tetapi hanya satu tujuan yang benar yaitu untuk memuliakan nama Tuhan. Namun, seringkali para pelayan / hamba Tuhan tidak memiliki motivasi yang benar sesuai dengan

${ }^{25}$ Bob Gordon, Motivasi Seorang Pemimpin, (Jakarta: Nafiri Gabriel, 2000), 15

${ }^{26}$ Donald S Whitney, Disiplin Rohani:10 Pilar Penopang Kehidupan Kristen, (Bandung: Literatur Baptis, 2001), 139-147 
statusnya sebagai pelayan Kristus. Hasil wawancara dengan JR (nama inisial) ia mengatakan bahwa kadang kala ia melayani bukan untuk kemuliaan Tuhan melainkan karena ingin mendapatkan pujian dari orang lain dan disegani karena ia seorang pelayan Tuhan di rumah Tuhan. ${ }^{27}$ Hal yang senada juga dengan A (nama inisial) mengatakan bahwa ia sering melayani hanya untuk mendapatkan pujian dari orang, dihormati dan dihargai. ${ }^{28}$

\section{Tidak Ada Kesungguhan Dalam Melayani}

Dalam melayani diperlukan kesungguhan dalam melayani Tuhan. Ketika seorang pelayan Tuhan memiliki kesungguhan dalam melayani maka memiliki prinsip yang benar sebagai pegangan dan pedoman dalam bertindak. Prinsip yang benar dalam melayani akan menghasilkan pelayanan yang memberkati banyak orang. Seorang pelayan yang memiliki prinsip yang benar akan melakukan tindakan apapun sebagai bentuk pelayanan kepada Tuhan dan sesama. Berdasarkan hasil wawancara dengan beberapa majelis gereja, mereka tidak melakukan pelayanan dengan sungguh-sungguh karena tidak mengerti apa yang menjadi prinsip pelayanan ketika mereka melayani Tuhan. Seorang yang melakukan pelayanan dengan sungguh-sungguh maka akan mengetahui siapa yang dilayani, memberi hati untuk melayani dan bertindak sesuai dengan apa yang Tuhan inginkan sebagai Pribadi yang memanggil untuk melayani Tuhan.

\section{Faktor Penyebab Problematika Integritas Pelayan Kristus Faktor Internal}

Istilah "internal" dalam Kamus Besar Bahasa Indonesia memiliki pengertian menyangkut bagian dalam (tubuh, mobil), ${ }^{29}$ artinya yang berasal dari dalam diri sendiri. Dengan demikian faktor internal adalah faktor yang mendorong seseorang dari dalam diri sendiri. Dalam melayani Tuhan, pelayan Tuhan sangat dipengaruhi oleh faktor internal yaitu faktor dari dalam diri sendiri. Dalam bagian ini, penulis akan membahas mengenai faktor internal yang mempengaruhi pelayan Kristus dalam melayani Tuhan yaitu belum lahir baru, tidak ada pertobatan tiap-tiap hari, belum memahami Firman Tuhan dan tidak melakukan fungsi sebagai pelayan Kristus.

\section{Belum Lahir Baru}

Seorang pelayan Tuhan adalah pribadi yang dipanggil dan dipilih oleh Allah untuk melakukan pekerjaan-Nya. Karena itu seorang pelayan Tuhan haruslah seorang yang mengalami pertobatan dan hidup baru. Namun dalam hal ini, sering juga ditemukan pelayan Tuhan yang belum lahir baru. Salah satu contoh adalah seorang pelayan Tuhan yang sudah melayani kurang lebih dua puluh dua tahun, melakukan tindakan yang seharusnya tidak dilakukan oleh seorang pelayan Tuhan. misalnya, merokok, minum-minuman keras bahkan berzinah. Sikap ini menandakan bahwa seorang pelayan Tuhan tersebut belum lahir baru. Dia hanya memiliki status pelayan Tuhan tanpa memaksimalkan fungsinya sebagai pelayan.

${ }^{27}$ JR, Majelis Jemaat, Wawancara Pribadi, Simangambat, 29 September 2014

${ }^{28}$ A, Majelis Jemaat, Wawancara Pribadi, Simangambat, 29 September 2014

29 Moeliono, Kamus Besar..., 336 


\section{Tidak Ada Pertobatan Tiap-tiap Hari}

Pemahaman seseorang terhadap pelayanan tidak dapat dilepaskan dari masalah pertobatan. Orang yang sudah bertobat atau mengalami lahir baru, akan dapat memahami bahwa begitu pentingnya hidup melayani Tuhan. Dengan kelahiran baru, maka seseorang dapat mengerti apa yang menjadi kehendak Allah dalam hidupnya. Sebaliknya orang yang belum mengalami kelahiran baru tidak akan mungkin mengerti kehendak Allah. Dengan demikian secara otomatis orang yang belum mengalami kelahiran baru tidak akan mungkin menjadi pelayan Tuhan yang setia.

Oleh karena itu pelayanan dapat meningkat dan bertumbuh jika para pelayan Tuhan sudah mengalami lahir baru. Lahir baru merupakan salah satu inti dari pengajaran Tuhan Yesus. Dalam Injil Yoh. 3: 3, ”.....sesungguhnya jika seseorang tidak dilahirkan kembali, ia tidak dapat melihat Kerajaan Allah" hal ini menandakan bahwa kelahiran baru merupakan suatu yang sangat penting dalam kehidupan orang percaya.

Pertobatan adalah syarat muthlak untuk beroleh keselamatan. ${ }^{30}$ Dalam Perjanjian Baru, kata "bertobat" pada umumnya merupakan terjemahan dari kata metanoin mempunyai arti tertentu tidak pernah berubah dalam sejarah perkembangan. Arti pokok kata ini tetap sama yaitu "berubah pikiran". Jadi, di dalam Perjanjian Baru pada dasarnya "pertobatan" bukan sesuatu yang berhubungan dengan emosi atau perasaan. Kata itu mengartikan suatu pengambilan keputusan, suatu penentuan sikap. Pertobatan yang benar menurut Alkitab itu artinya hanya satu, yaitu mengambil keputusan yang tegas di dalam hati atau berubah pikiran. $^{31}$

Selain itu, hal yang paling menarik untuk diperhatikan bahwa di dalam Perjanjian baru dimulai (Mat. 3: 2) dan diakhiri (Why. 3: 19) dengan panggilan untuk bertobat. ${ }^{32}$ Fakta ini membuat William D. Chamberlain mengatakan bahwa:

Fakta penting bagi tujuan kita adalah bahwa pesan pertama dan terakhir yang digoreskan di dalam Perjanjian Baru adalah pertobatan. Ini merupakan pesan yang paling Universal di dalam Perjanjian Baru, bahkan lebih Universal dari pada kebangkitan. Adalah sangat bernilai untuk melihat di dalam terang fakta ini bahwa kepercayaan akan kebangkitan inilah yang memungkinkan penyampaian khotbah. Pertobatan memberikan tujuan bagi khotbah Krsiten. ${ }^{33}$

Berdasarkan wawancara dengan MO, ia mengatakan bahwa mengetahui lahir baru, tetapi tidak ada tindakan nyata yang tampak dari kehidupannya yang menyatakan bahwa ia bertobat tiap-tiap hari dan sudah mengalami lahir baru (Yak. 2: 14-26). Pertobatan adalah meninggalkan kebiasaan lama. MO mengatakan bahwa pertobatan itu milik semua orang tanpa terkecuali. Selain itu, MO mengatakan bahwa karena kita masih hidup di dalam dunia ini maka masih hidup dalam dosa, bagaimana mau bertobat? kalau sebentar lagi buat dosa lagi. ${ }^{34}$ Demikian juga dengan SM, ia mengatakan bahwa mengerti tentang arti pertobatan itu. Tetapi karena masih di dunia pasti akan jatuh dalam dosa lagi. ${ }^{35}$

${ }^{30}$ J. D Douglas, Ensiklopedi Alkitab Masa Kini Jilid II, (Jakarta: Yayasan Komunikasi Bina Kasih,

${ }^{31}$ Derek Prince, Bertobat dan Percaya, (Jakarta: Yayasan Pekabaran Injil IMMANUEL, 1993), 9

${ }^{32}$ Anthony A. Hoekema, Diselamatkan Oleh Anugerah, (Surabaya: Momentum, 2001), 172

${ }^{33}$ William D. Chamberlain, The Meaning of Repentence, (Philadelphia: Westminster, 1943), 80

${ }^{34}$ MO, Majelis Jemaat, Wawancara Pribadi, Trans Pir Unit II, 29 September 2014

${ }^{35}$ SM, Majelis Jemaat, Wawancara Pribadi, Trans Pir Unit V, 29 September 2014 
Dengan demikian, dapat disimpulkan bahwa Orang yang sungguh-sungguh mengalami lahir baru kehidupannya sesuai dengan Firman Tuhan. Dari penelitian penulis belum semua pelayan Tuhan hidup sesuai dengan Firman Tuhan. Maka masih perlu pembimbingan secara pribadi kepada pelayan Tuhan supaya hidup takut akan Tuhan.

\section{Belum Memahami Firman Tuhan}

Alkitab adalah Firman Allah merupakan perkataan Allah, di mana Allah berbicara kepada manusia secara tertulis. Alkitab adalah Firman Allah yang menjadi otoritas dan satusatunya landasan praktik kehidupan bagi orang percaya. Alkitab adalah Firman Allah, yang ditulis oleh orang-orang yang dipakai oleh Allah (menerima wahyu dan ilham Allah, digerakkan dan dinafaskan Allah)(2 Timotius 3: 16; 2 Petrus 1:20-21). Seharusnya seorang pelayan Tuhan melakukan pengajaran yang benar akan firman Tuhan. Oleh karena Firman Tuhan menjadi dasar utama di dalam melayani Tuhan. Tetapi jika dilihat dari cara para pelayan melayani, maka sangat kurang layak untuk dicontoh. Baik melalui pengajarannya, maupun teladan hidup mereka secara pribadi.

Salah satu contoh yang penulis cermati adalah pada saat menyampaikan Firman Tuhan masih ada yang menyimpang dari kebenaran tidak sesuai dengan apa yang dikatakan. Contoh: jangan merokok, karena tubuh ini adalah Bait Suci Allah, jangan berjudi, jangan minum-minuman keras, berzinah dsb. Pada hal para majelis sendiri juga masih jatuh dengan dosa yang sama.

Berdasarkan hasil wawancara dengan $\mathrm{M}$, ia mengatakan bahwa Alkitab adalah kebenaran Allah, Firman Allah yang dapat mengubah hidup menjadi lebih baik. ${ }^{36}$ Tetapi, fakta sehari-hari yang terjadi berbeda dengan apa yang dikatakan. Misalnya: ketika mengalami sakit penyakit masih pergi ke dukun untuk disembuhkan, mau kaya pergi ke pesugihan. Pada hal, Firman Tuhan nyata kebenaran Allah yang mampu memberi segalanya, kekuatan, penghiburan dan penyembuhan.

Salah satu yang menjadi faktor problematika bagi para pelayan belum memahami Firman Tuhan sebagai kebenaran Allah dan dasar kehidupan sebagai orang percaya.

\section{Tidak Melakukan Fungsi Sebagai Pelayan Kristus}

Dalam Perjanjian baru kata "melayani" digunakan dalam banyak arti. Ada empat macam kata yang digunakan dalam bahasa aslinya yaitu diakoneo, douleo, leitourgeo dan latreuo. Diakoneo artinya menggunakan karisma yang ada untuk kepentingan dan kebaikan orang lain (1Pet. 4: 10). Douleo artinya menghamba yang dilakukan oleh seorang doulos (budak). ${ }^{37}$ Selanjutnya, leitourgeo berarti bekerja untuk kepentingan rakyat atau kepentingan umum, bukan untuk kepentingan diri sendiri (1Kor. 9: 12). Latreuo dalam Roma 12: 1 berarti mempersembahkan tubuh kepada Tuhan sebagai persembahan yang pantas. ${ }^{38}$

Beberapa pelayan Tuhan tidak mengetahui fungsinya sebagai pelayan Tuhan oleh karena tidak adanya kesungguhan dalam melayani. Kesungguhan dalam melayani tidak lepas dari pertobatan atau lahir baru, jika seseorang sudah lahir baru maka ia mengetahui bahwa pentingnya pelayanan dan dapat melakukan fungsinya sebagai pelayan Tuhan dengan baik. Tetapi berdasarkan pengamatan penulis bahwa para pelayan Tuhan tidak mengetahui apa fungsinya sebagai pelayan Kristus karena kurangnya pemahaman yang benar tentang arti melayani.

\footnotetext{
${ }^{36}$ M, Majelis Jemaat, Wawancara Pribadi, Trans Pir Unit V, 29 September 2014

${ }^{37}$ Andar Ismail, Selamat Melayani Tuhan, (Jakarta: BPK Gunung Mulia, 1996), 2-3

${ }^{38}$ Ibid., 4
} 


\section{Faktor Eksternal}

Dalam bagian ini akan di bahas munculnya masalah dalam pelayanan para pelayan Tuhan bukan hanya disebabkan dari dalam diri sendiri, melainkan juga faktor dari luar diri para pelayan Tuhan. Dalam bagian ini, penulis akan membahas mengenai faktor eksternal yang mempengaruhi pelayan Kristus dalam melayani Tuhan yaitu keluarga dan lingkungan.

\section{Keluarga}

Keluarga adalah satu rumah tangga yang terdiri dari suami, isteri dan anak. Suami berfungsi sebagai kepala keluarga yang harus memenuhi kebutuhan keluarga. Seorang isteri bertugas untuk mengurus urusan rumah tangga. Sedangkan anak harus taat kepada kedua orang tua. ${ }^{39}$ Berdasarkan hasil pengamatan penulis di lapangan bahwa majelis sangat memungkinkan untuk tidak menjadi teladan dan berkat bagi keluarga sehingga keluarga tidak mendukung mereka sebagai pelayan Tuhan. Bahkan keluarga yang salah satu anggotanya pelayan Tuhan menjadi batu sandungan bagi orang yang mereka layani. Sehingga dapat disimpulkan bahwa keluarga masih tetap menjadi salah satu faktor penyebab problematika integritas pelayan Tuhan oleh karena bagaimana mau melayani jemaat, kalau keluarga saja tidak bisa ditangani.

\section{Lingkungan}

Lingkungan tempat tinggal sangat mempengaruhi pola hidup seseorang. Manusia sebagai makhluk sosial, manusia tidak dapat hidup terpisah dari lingkungan di mana ia tinggal. Menurut Poerwadarminta lingkungan adalah sekeliling dan sekitar. ${ }^{40}$ Demikian juga dengan para pelayan Tuhan, beberapa di antara mereka yang bertempat tinggal di tengahtengah lingkungan orang Muslim, sehingga itu mempengaruhi semangat, tanggungjawab, ketaatan dan kesetiaan mereka untuk melayani.

Berdasarkan hasil wawancara yang telah penulis lakukan dengan EB, ia mengatakan bahwa seringkali pelayanannya terhambat oleh karena banyaknya pekerjaan yang tidak dapat ditinggalkan, sehingga menomor duakan pelayanan. Pelayanan bisa dilakukan lain waktu, tetapi pekerjaan tidak dapat ditunda selagi masih hidup di dunia ini. ${ }^{41}$

Demikian juga hasil wawancara dengan $\mathrm{M}$, ia mengatakan bahwa lingkungannya mempengaruhi keaktifannya untuk melayani, oleh karena jika ada tetangganya sedang pesta, baik pesta pernikahan, sunatan, arisan dll, maka $M$ segan untuk meninggalkannya sehingga tidak pergi pelayanan. ${ }^{42} \mathrm{Jadi}$, dapat disimpulkan bahwa keadaan lingkungan sangat mempengaruhi pelayanan.

\section{DAMPAK PROBLEMATIKA PELAYAN KRISTUS}

\section{Bagi Diri Sendiri}

Setiap orang percaya yang lebih menuruti keinginannya sendiri lebih dari apa yang dikehendaki oleh Tuhan itu berarti telah mengingkari panggilan Tuhan. Panggilan Tuhan terhadap orang percaya adalah melakukan kehendak-Nya, mengingkari panggilan Allah berarti menjalin persahabatan dengan dunia, persahabatan dengan dunia mendatangkan murka Allah atas diri orang percaya (Rm. 2: 5-9).

Selain itu setiap orang yang tidak melaksanakan panggilan Tuhan maka ia juga tidak akan memperoleh damai sejahtera dalam hidupnya, karena damai akan dirasakan oleh setiap

\footnotetext{
${ }^{39}$ Harry Blaimeres, The Post Christian Mind, (Surabaya: Momentum, 2003), 22

${ }^{40}$ Poerwadarminta, Kamus Umum Bahasa Indonesia, (Jakarta: Balai Pustaka, 1997), 601

${ }^{41}$ EB, Majelis Jemaat, Wawancara Pribadi, Trans Pir Unit V, 30 September 2014

${ }^{42}$ M, Majelis Jemaat, Wawancara Pribadi, Trans Pir Unit V, 30 September 2014
} 
orang yang melakukan kehendak Tuhan termasuk orang yang melayani Tuhan dengan benar. (Yes. 32: 17; Rm. 2: 10). Melalui hasil wawancara penulis, salah satu dari Majelis mengatakan bahwa:

Selama bertahun-tahun melayani, dia merasakan bahwa pelayanan yang dia lakukan bukan karena mengasihi jiwa-jiwa yang Tuhan berikan (Jemaat), melainkan hanya rasa tanggung jawab yang sudah diembannya sebagai Majelis (jabatan) oleh karena rutinitas saja. Bukan berarti memberi diri sepenuhnya kepada pekerjaan Tuhan. Ia sering melayani tanpa persiapan yang baik, melayani dengan separuh hati serta bermalas-malasan karena pada dasarnya dia melayani oleh karena rutinitas yang diembannya. ${ }^{43}$

Dengan demikian setiap orang percaya harus tetap hidup sesuai dengan kehendak Tuhan, hidup melayani Tuhan, maka damai sejahtera akan menjadi bagian dalam hidupnya.

\section{Bagi Keluarga}

Keluarga adalah rencana Allah yang seharusnya menjadi dasar sukacita dan kebahagiaan, keluarga juga merupakan sumber kebahagiaan dan tempat pembentukan kepribadian dan iman anak. ${ }^{44}$ Oleh karena itu untuk mewujudkan keluarga yang harmonis dan takut akan Tuhan maka diharapkan untuk hidup melakukan kehendak Tuhan. Sesuai hasil wawancara dan penelitian yang telah penulis lakukan bahwa banyak pelayan Tuhan yang tidak bertumbuh secara rohani. Oleh karena itu, banyak keluarga yang mengeluh dengan sikap yang dimiliki oleh para Majelis yang melayani di rumah Tuhan yang tidak sesuai dengan kehendak Tuhan.

\section{Bagi Gereja}

Gereja adalah kumpulan orang-orang yang menyadari akan panggilan Allah untuk beribadah memuliakan Allah. ${ }^{45}$ Gereja yang bertumbuh tidak hanya dinilai dari pertumbuhan secara kuantitas, dan materinya saja melainkan pertumbuhan kualitas pelayananya juga. Gereja yang bertumbuh dilihat juga dari para pelayannya dalam melayani Tuhan.

Para Majelis yang tidak sungguh-sungguh melayani Tuhan tentunya tidak akan memahami kehendak Tuhan, sehingga orang yang tidak memahami kehendak Tuhan maka hidupnya tidak akan menjadi berkat. Sesuai dengan wawancara yang telah penulis lakukan dengan IS (nama inisial) ia mengatakan bahwa gereja tidak akan mengalami pertumbuhan jika para Majelis tidak memahami arti Pentingnya Integritas pelayan Kristus sebagai pelayan Tuhan. Dari uraian tersebut dapat disimpulkan bahwa Integritas pelayan Kristus sangatlah penting dan sangat berdampak bagi pertumbuhan gereja.

Berdasarkan penjelasan yang telah diuraikan, maka penulis dapat menyimpulkan bahwa yang menjadi problematika integritas pelayan Kristus adalah sebagai berikut: tidak

${ }^{43}$ E, Majelis Jemaat, Wawancara Pribadi, Trans Pir Unit V, 29 September 2014

${ }^{44}$ W. Stanlay Heath, Theologia Pendidikan Anak, Dasar Pelayanan Kepada Anak, (Bandung:

Yayasan Kalam Hidup, 2005), 26

45 Jeremia Rim, Iman yang Hidup dan Berkuasa, (Yokyakarta: Yayasan Andi, 1995), 192 
memiliki panggilan yang jelas, tidak memiliki motivasi yang benar dalam melayani dan tidak adanya kesungguhan dalam melayani yang dilakukan hanya sebatas rutinitas saja.

Problematika ini di sebabkan beberapa faktor antara lain: faktor internal yaitu faktor yang berasal dari dalam diri seseorang seperti belum lahir baru, tidak ada pertobatan tiaptiap hari, belum memahami Firman Tuhan dan tidak melakukan fungsinya sebagai pelayan Kristus. Sedangkan faktor eksternal ialah berasal dari luar diri seseorang seperti keluarga dan lingkungan serta berdampak bagi diri sendiri, bagi keluarga dan bagi gereja.

\section{Pentingnya Integritas Pelayan Kristus Menurut Titus 1:6-9 Dalam Upaya Peningkatan Pelayanan Gerejawi}

\section{Integritas Pelayan Kristus}

Integritas seorang pelayan merupakan suatu sikap yang harus dimiliki sebagai pelayan Kristus. Dalam hal ini akan diuraikan tentang pemahaman pentingnya integritas pelayan Kristus antara lain: pertobatan, memiliki hubungan pribadi dengan Tuhan, memiliki kepribadian yang baik, menjadi saksi melalui sikap hidup, memiliki prinsip yang benar dalam melayani dan memiliki pengajaran yang benar.

\section{Pertobatan}

Para pelayan Tuhan seharusnya sudah mengalami pertobatan terlebih dahulu. Sehingga setiap orang percaya yang melayani karena sudah diselamatkan. Pertobatan berarti komitmen kepada Tuhan sebagai respon dari kasih karunia-Nya dan dinyatakan dalam pertobatan yang sesungguhnya serta dalam iman. ${ }^{46}$ Dalam bukunya yang berjudul "Hidup Kristen yang berubah" Stephen Tong menuliskan tentang pertobatan.

Ada hal yang sangat penting untuk diingat bahwa ada hati pertobatan dan buah pertobatan. Hati pertobatan ada di dalam sedangkan buah pertobatan ada di luar. Hati pertobatan adalah suatu niat, sedangkan buah pertobatan adalah perbuatan. Hati pertobatan dilihat oleh Tuhan Yesus sedangkan buah pertobatan disaksikan oleh manusia. Pertobatan mempunyai dua aspek besar. Aspek di dalam dan aspek di luar. Pertobatan bukan merupakan suatu pengakuan di mulut atau suatu pengakuan di otak semata-mata. Pertobatan bukan merupakan suatu ide keinginan berbuat baik semata-mata, tetapi perbuatan sifat dasar dari sikap hidup dan arah hidup dari kegelapan menuju kepada terang yang diperkenan oleh Tuhan. Pertobatan adalah betul-betul membenci dosa dan kembali kepada Tuhan, berkenan di hadapan Tuhan Allah, hati pertobatan bukan suatu hal yang lahiriah, melainkan suatu perubahan total dalam jiwa. Allah memberikan hidup baru kepada seseorang, sehingga melalui hidup baru itu menghasilkan sesuatu perasaan benci kepada dosa. 47

Oleh karena itu, dalam bagian ini penulis akan menjelaskan pelayan Tuhan yang mengalami pertobatan, antara lain yaitu harus lahir baru dan mendapatkan pengampunan.

\section{Lahir Baru}

Titus adalah anak Paulus yang sah menurut iman mereka bersama. Ada kemungkinan besar bahwa ini berarti Titus bertobat melalui pelayanan pribadi yang dilakukan oleh Paulus.

${ }^{46}$ J. I. Packer, Kristen Sejati Volume II, (Jakarta: Lembaga Reformed Injili Indonesia, 1992), 14

${ }^{47}$ Stephen Tong, Hidup Kristen yang Berubah.( Jakarta: Lembaga Reformed Injili Indonesia, 1992), 
Pelayanan yang dilakukannya oleh karena Titus telah mengalami pertobatan dan lahir baru. Stephen Tong menuliskan dalam bukunya bahwa pertobatan ialah sifat berubah total dengan keinginan yang sungguh-sungguh untuk mengalami anugerah di dalam Kerajaan Allah. ${ }^{48}$

Seseorang yang mengalami pertobatan dan lahir baru seperti Titus hidupnya tidak akan seperti orang yang hidup bercacat dihadapan Tuhan. Paulus mau menekankan kepada Titus bahwa sebagai syarat penatua jemaat harus hidup baru atau mengalami pertobatan karena Paulus sangat menekankan kualitas rohani daripada jasmani.

Para pelayan Tuhan yang melayani harus mengalami pertobatan dan lahir baru terlebih dahulu. Pertobatan dan lahir baru dapat dilaksanakan dengan cara pelayanan pribadi seperti yang dilakukan Paulus terhadap Titus. Seorang yang sudah melaksanakan pelayanan pribadi akan mengalami lahir baru, maka akan mengalami perjumpaan secara pribadi dengan Tuhan Yesus dan mengerti kepada siapa tujuan hidup yang akan diberikan. Dengan demikian, para pelayan Tuhan dapat menjadi teladan bagi orang lain karena telah mengalami pembaharuan dalam hidupnya.

\section{Pengampunan}

Seorang pelayan Tuhan yang sudah hidup baru sudah menyadari akan keberadaan yang sesungguhnya tidak layak dihadapan Tuhan karena dosa-dosanya. Namun Tuhan telah memberikan anugerah kepada para pelayan Tuhan yang mau percaya kepada Tuhan. Anugerah pengampunan yang Tuhan berikan bagi setiap pelayan Tuhan melayakkan para pelayan Tuhan untuk melayani Tuhan melalui seluruh eksistensi kehidupannya. Dengan demikian, para pelayan Tuhan yang hidupnya sudah dilayani secara pribadi dengan adanya pengakuan dosa maka akan mendapatkan pengampunan dari Tuhan bebas dari ikatan dosa yang mengikatnya. Sehingga para pelayan dapat meningkatkan pelayanan di Padang Lawas secara khusus di daerah Sosa.

\section{Memiliki Hubungan Pribadi Dengan Tuhan}

Status Titus sebagai seorang anak. Seorang anak mengindikasikan kedekatan seorang bapak dengan anaknya. Inilah yang mengharuskannya memiliki intimasi dengan Tuhan. Seorang anak tidak akan mengetahui kehendak bapaknya jika ia tidak bertanya kepada bapaknya. Kedekatan seorang anak dengan bapaknya akan membuat ia mengerti apa yang bapaknya perintahkan untuk dilakukan. Demikian juga Titus, intimasinya dengan Tuhan yang mengakibatkan ia semakin memahami kehendak Tuhan dan semakin menjadi berkat di tengah-tengah lingkungannya. Ia tahu apa yang menyenangkan hati Bapa-Nya yaitu Tuhan Yesus.

Dengan demikian, dalam bagian ini penulis akan menguraikan pelayan Tuhan yang memiliki hubungan Pribadi dengan Tuhan, antara lain yaitu iman, kasih dan pengorbanan.

\section{Iman}

Di dalam surat Ibrani mengatakan bahwa Iman adalah dasar dari segala sesuatu yang kita harapkan dan bukti dari segala sesuatu yang tidak kita lihat. Dereck Prince menuliskan iman sebagai kepercayaan atau keyakinan seseorang kepada apa yang dipercayai. Setiap orang pasti memiliki iman dan iman tersebut tergantung kepada siapa yang ia percaya. ${ }^{49}$ Ketika orang percaya sudah menerima Tuhan Yesus sebagai Tuhan dan Juruselamat secara pribadi maka hidupnya memiliki kepercayaan atau iman kepada Tuhan yang disembahnya.

Hidup beriman adalah salah satu wujud kepercayaan seseorang percaya kepada Tuhan-Nya. Hidup beriman dapat dilakukan dengan mengandalkan Tuhan dalam kehidupan

\footnotetext{
${ }^{48}$ Stephen Tong, Kerajaan Allah, Gereja dan Pelayanan, (Surabaya: Momentum, 2001), 64 1994), 10

49 Derek Prince, Iman yang Olehnya Kita Hidup, (Jakarta: Yayasan Pekabaran Injil "IMMANUEL",
} 
sehari-hari sebagai orang yang percaya kepada Tuhan-Nya. Titus melakukan hal demikian karena dia tahu bahwa Allah yang memberi panggilan itu kepadanya melalui rasul Paulus sehingga Ia mengandalkan Tuhan dalam kehidupannya. Dengan demikian, para pelayan Tuhan harus memiliki iman kepada Tuhan yang dipercayainya yaitu Yesus Kristus yang memberi panggilan dan pelayanan. Sehingga dalam melayani Tuhan selalu mengandalkan Tuhan dan ada keyakinan yang pasti kepada Tuhan-Nya yang memberi anugerah keselamatan kepada setiap orang yang percaya kepada-Nya.

\section{Kasih}

Salah satu sifat Allah adalah kasih dan Ia telah membuktikan kasih itu di dalam Tuhan Yesus yang mati di atas kayu salib untuk manusia. Kasih lebih besar daripada iman dan pengharapan. Kasih adalah hal yang terbesar dan terutama dalam dunia ini. ${ }^{50}$ Kekuatan kasih Kristus menolong anak-Nya hidup mengasihi sesama dengan motivasi dan tujuan yang benar. Kasih sayang yang dimiliki seorang pelayan Kristus adalah tanpa pamrih, penuh kemurahan, kebaikan, rendah hati dan rela berkorban. ${ }^{51}$ Kasih merupakan sesuatu yang penting dalam kehidupan orang Kristen. Hidup orang Kristen sesungguhnya merupakan rangkaian kesempatan untuk menyatakan kasih kepada Tuhan, sesama dan seluruh ciptaan. Tanpa kasih kehidupan orang percaya menjadi sia-sia. ${ }^{52}$ Demikian Titus dalam kehidupan dan pelayanannya. Titus mendasari pelayanannya dengan kasih yang dari Tuhan sehingga dia mau melayani orang-orang yang ada di Kreta pada waktu itu yang sifatnya jahat.

Para pelayan Tuhan seharusnya memiliki kasih yang dari Tuhan. Kasih itu dapat diwujudkan dengan melakukan tindakan nyata yang dapat dilihat dan dirasakan oleh orangorang yang disekitarnya. Tindakan tersebut berupa perkunjungan dan mendoakan jemaat yang dilayani. Dengan demikian, kasih itu dapat diaplikasikan secara langsung bukan hanya teori. Sehingga dalam pelayanan banyak orang diberkati melalui pelayanan yang dilakukan. Dalam Matius 22: 37 \& 39, mengatakan bahwa mengasihi Tuhan Allah dengan segenap hati, segenap jiwa dan segenap akal budi serta mengasihi sesama seperti diri sendiri. Dengan demikian, para pelayan Tuhan menjadi teladan dan berkat bagi sesamanya.

\section{Pengorbanan}

Rela berkorban merupakan suatu tuntutan dalam melakukan pelayanan. Mengorbankan tenaga, waktu, materi, pikiran dan harga diri. Dalam hal lain juga mungkin harus mengorbankan kepentingan dan kesenangan diri sendiri demi pelayanan. Tuhan Yesus melakukan pelayanan, banyak hal yang Ia korbankan. Untuk tenaga Ia harus berjalan menyusuri jalan berbatuan, berjalan dari suatu kota ke kota lain. Untuk waktu, Ia menghabiskan waktu-Nya untuk melayani, menyembuhkan yang sakit dan menghibur orang yang terluka, untuk pikiran, Ia harus memikirkan orang-orang yang di sekeliling-Nya supaya mereka tidak kelaparan. ${ }^{53}$ Titus melakukan pelayanannya tidak memikirkan berapa imbalan yang dia terima, menghabiskan masa mudanya untuk kepentingan orang lain serta mengabdikan diri sebagai uskup di Kreta selama hidupnya. Jika seandainya seorang pelayan Tuhan tidak mendapat apa-apa dalam pelayanannya, itu merupakan bagian hal yang terkecil, yang harus dirasakan dan dialami oleh setiap pelayan Tuhan dibandingkan dengan apa yang sudah Tuhan Yesus lakukan dalam kehidupan orang percaya. ${ }^{54}$

${ }^{50}$ J. Wesley Brill, Dasar Yang Teguh, (Bandung: Kalam Hidup, tt), 266

${ }^{51}$ Eddy Fances, Mengenal dan Dikenal Allah (Jakarta: Yasinta, 2003), 108

${ }^{52}$ U. T. Saputra, Beriman di Kancah Kehidupan, (Bandung: Bina Media Informasi, 2005), 49

${ }^{53}$ Ijois Simorangkir, Konsep yang Baik, (Tanjung Enim: STTE, 2012), 95

54 Warren W. Wiersbe, 10 Kekuatan Pelayanan yang Alkitabiah, (Jakarta: Yayasan Andi, 2010), 
Sikap rela berkorban inilah yang harus dimiliki oleh pelayan Tuhan, tidak mengharapkan imbalan dari setiap pelayanannya. Pengorbanan dalam pelayanan merupakan suatu nilai yang tertinggi, yang sudah diperhitungkan oleh Allah. pelayan yang melayani Tuhan dengan pengorbanan akan melakukan segala sesuatu dengan tulus, meskipun pengorbanan yang dilakukan tidak diperhitungkan oleh orang lain, namun yakin dan percaya bahwa Tuhan memperhitungkan apa yang dilakukan untuk kemuliaan-Nya.

\section{Memiliki Kepribadian Yang Baik}

Kehidupan sebagai orang percaya diberkati untuk menjadi berkat. Diselamatkan untuk melayani. ${ }^{55}$ Statement yang benar dan harus diaplikasikan. Andar Ismail dalam bukunya "Selamat Melayani" memberikan suatu gambaran mengenai pelayanan yang menjadi berkat ${ }^{56}$ :

"Sebuah pemberian yang keluar sebagai ungkapan pelayanan kasih dapat menimbulkan keajaiban. Sepotong roti keriput bisa menimbulkan senyum indah. Sepotong roti keras dapat menimbulkan kegembiraan. Sepotong roti kecil bisa menimbulkan pengharapan. Sepotong roti kering bisa menimbulkan titik-titik air mata. Air mata haru orang yang menerima dan air mata bahagia orang yang memberi. Memberi dari kekurangan adalah luapan hati. Suatu keajaiban jika seseorang dapat memberi dari kekurangannya".

Pernyataan di atas telah banyak terbukti dalam kehidupan manusia sehari-hari dan hal inilah yang telah dilakukan Paulus, ia telah menjadi berkat bagi orang lain dengan sikap hidup yang telah diubahkan Tuhan. Salah satunya adalah anak iman mereka yang bernama Titus. Paulus mau supaya Titus walaupun dalam usianya yang muda bisa menjadi berkat bagi orang-orang yang ada di Kreta pada waktu itu melalui kepribadiannya yang baik terhadap Tuhan dan sesamanya. Kepribadian yang baik dapat diwujudkan dengan memiliki kasih sayang dan tidak mementingkan diri sendiri. Sehingga Titus dapat melanjutkan pelayanan Paulus untuk mengangkat para penatua-penatua jemaat di setiap kota sehingga dia tidak tertolak dengan apa yang diajarkan karena tidak sesuai dengan perkataan dan tindakannya.

\section{Memiliki Kasih Sayang}

Jika berbicara tentang mengasihi, sebatas kata-kata saja, kelihatannya sangat mudah, tetapi jika diimplementasikan dalam kehidupan nyata sangat sulit. ${ }^{57}$ Kasih dapat membuat seseorang melakukan segala sesuatu yang terbaik untuk orang yang dikasihinya, meskipun ada harga yang harus dibayar. Kasih dapat diwujudkan dalam tindakan nyata. ${ }^{58}$

Para pelayan Tuhan harus memiliki kasih sayang dalam melayani Tuhan sehingga banyak orang diberkati melalui pelayanan yang dilakukan. Memiliki kasih sayang diwujudkan dengan tindakan, seperti: mempedulikan sesama yang membutuhkan, melakukan perkunjungan pastoral serta mendoakan. Allah telah lebih dahulu mengasihi anak-Nya dan kasih Allah itulah yang harus disaksikan kepada banyak orang dalam melayani Tuhan. Sebagai seorang pelayan Kristus juga harus memiliki kasih yang nyata yaitu melalui tindakan, bukan hanya sekedar kata-kata saja.

\footnotetext{
${ }^{55}$ Rick Warren, The Purpose Driven Life, (Jawa Timur: Gandum Mas, 2011), 249

${ }^{56}$ Andar Ismail, Selamat Melayani Tuhan, (Jakarta: BPK Gunung Mulia, 1996), 61

${ }^{57}$ Paulus Daun, Kristen yang Bertumbuh, (Manado: Yayasan Daun Family, 2008), 80

${ }^{58}$ Michael Griffiths, Ambillah Aku Melayani Engkau, (Jakarta: BPK Gunung Mulia, 1975), 47
} 


\section{Tidak Mementingkan Diri Sendiri}

Seorang pelayan Tuhan yang memiliki kepribadian yang baik tidak akan mementingkan diri sendiri melainkan memberi diri untuk setulus hati menolong dan memperhatikan orang lain tanpa mengharapkan imbalan dalam bentuk apapun. Memberi diri adalah berkorban. Gaya hidup memberi diri sesungguhnya melawan arus yang lazim, sebab kebanyakan orang justru berpola hidup mengarah kepada kepentingan diri sendiri. ${ }^{59}$ Bahkan Titus dalam melayani Tuhan, dia tidak mementingkan dirinya sendiri, dia rela dalam masa muda memberi diri dalam pelayanan karena dia tahu bahwa orang-orang yang di Kreta membutuhkannya.

Para pelayan Tuhan seharusnya mengutamakan kepentingan orang lain, bukan dirinya sendiri. Inilah kerendahan hati yang sejati: bukan menganggap diri kurang, melainkan kurang memikirkan diri sendiri. Berhentilah untuk memfokuskan diri kepada kebutuhankebutuhan diri sendiri, sadarlah akan kebutuhan orang-orang yang ada di sekitar. Jangan melayani hanya ingin disukai atau dikagumi oleh orang lain dan supaya tujuan diri sendiri tercapai. Ini adalah manipulasi, bukan pelayanan. ${ }^{60}$

Hal inilah seharusnya dimiliki para pelayan Tuhan tidak mementingkan diri sendiri dengan kesibukan yang tidak jelas sehingga pelayanan terbengkalai melainkan mementingkan pelayanan yang Tuhan percayakan untuk dilakukan. Seharusnya para pelayan Tuhan memiliki komitmen yang jelas dalam melayani Tuhan, diperlengkapi dengan pengajaran dan pemahaman Alkitab yang lebih dalam lagi. Dengan demikian, pelayanan meningkat dengan baik karena adanya integritas yang dimiliki seorang pelayan Tuhan.

\section{Menjadi Saksi Melalui Sikap Hidup}

Orang yang hidup percaya didalam Tuhan Yesus Kristus harus memiliki sikap hidup yang menjadi saksi bagi banyak orang, baik kepada sesama orang percaya maupun kepada orang yang tidak percaya. Dalam bagian ini, penulis akan menjelaskan menjadi saksi melalui sikap hidup, diantaranya yaitu memiliki motivasi yang benar dalam melayani dan memiliki jati diri sebagai pemberita Injil.

\section{Memiliki Motivasi Yang Benar Dalam Melayani}

Motivasi Titus dalam melayani Tuhan ialah agar banyak orang mendengarkan perbuatan dan kuasa Tuhan Yesus, sampai pada akhirnya banyak orang percaya kepada Tuhan Yesus Kristus.

Motivasi yang benar dalam melayani Tuhan inilah yang harus dimiliki pelayan Kristus. Dengan memiliki motivasi benar dalam melayani, maka pelayanan apapun yang dilakukan akan menyenangkan hati Tuhan dan semakin banyak orang rindu untuk mengenal Tuhan Yesus dan menerima-Nya sebagai Tuhan dan Juruselamat pribadi.

\section{Memiliki Jati Diri sebagai Pemberita Injil}

Kesaksian hidup orang Kristen yang terkuat adalah kesaksian yang diucapkan oleh seorang percaya yang kehidupannya sesuai dengan Firman Tuhan. Titus telah membuktikan bahwa hidupnya memiliki jati diri sebagai pemberita Injil. Ia bukanlah orang yang gemar untuk banyak berbicara. Ia lebih suka untuk banyak bertindak. Tindakan yang dilakukan oleh Titus telah menyampaikan banyak pesan kepada orang-orang disekitarnya.

Dengan demikian, para pelayan Tuhan seharusnya banyak bertindak atau melakukan sesuai dengan diucapkan Firman Tuhan yaitu memiliki jati diri dalam melayani Tuhan bukan hanya banyak bicara tidak ada tindakan (action), sehingga ada keseimbangan baik secara

\footnotetext{
${ }^{59}$ Andar Ismail, Selamat Melayani Tuhan (Jakarta: Gunung Mulia, 1996), 86

${ }^{60}$ Warren, The Purpose Driven..., 291-292
} 
teori maupun secara praktis dalam kehidupan sehari-hari. Oleh karena itu, sebagai pelayan Tuhan milikilah jati diri sebagai pemberita Injil yang baik.

\section{Memiliki Prinsip Yang Benar Dalam Melayani}

Dalam melayani Tuhan diperlukan prinsip yang benar sebagai pegangan dan pedoman dalam bertindak. Prinsip yang benar dalam melayani akan menghasilkan pelayanan yang memberkati banyak orang. Seorang pelayan yang memiliki prinsip yang benar akan melakukan tindakan apapun sebagai bentuk pelayanan kepada Tuhan dan sesama.

Pegangan seorang pelayan yang memiliki prinsip hidup yang benar dalam pelayanan adalah seorang yang mengetahui pegangan utamanya dalam melayani Tuhan yaitu perkataan yang dapat di percaya, yaitu Injil yang murni. Injil itu hanya dapat dikatakan murni, kalau ia sesuai dengan ajaran yang sehat, yaitu ajaran rasuli. Prinsip hidup dalam pelayanan yang benar sadar akan tugasnya sebagai seorang pelayan Tuhan, mengetahui siapa yang dilayani dan memberi hati untuk melayani Tuhan dan sesama.

\section{Mengetahui Siapa Yang Dilayani}

Seorang Pelayan Tuhan adalah seorang yang dikhususkan dalam panggilan Allah. Para pelayan Tuhan harus menyadari bahwa hanya Allah yang memanggilnya dalam melayani. Sehingga kekeliruan para pelayan Tuhan masa kini, seperti pemahaman yang kabur dan salah akan siapa yang memanggil dalam tugas melayani dan keragu-raguan akan Allah yang memanggil tidak ditemukan lagi. Titus sebagai pelayan Tuhan menyadari siapa yang memanggilnya menjadi pelayan Tuhan yaitu Allah sendiri melalui Paulus yang mempercayakan pelayanan untuk menentukan penilik gereja yang ada di Kreta pada waktu itu. Bahkan Ia melayani tidak memiliki motivasi untuk kemuliaan dirinya sendiri karena ia tahu bahwa kemuliaan hanya bagi Tuhan yang telah memanggilnya dan memakainya sebagai alat-Nya.

Jadi, para pelayan Tuhan seharusnya menyadari bahwa hanya Allah yang memanggil dan memberi pelayanan yang berharga untuk dilakukan untuk kemuliaan nama Tuhan tidak mencari pujian bagi diri sendiri. Sehingga dalam melayani Tuhan tidak mencari keuntungan diri sendiri melainkan untuk kemuliaan nama Tuhan.

\section{Memberi Hati Dalam Melayani}

Di dalam melayani Tuhan yang terpenting adalah memberi hati dalam melayani. Ketika seseorang tidak memberikan hati dalam melayani Tuhan maka pelayanan yang dilakukan tidak memiliki arti dan kesan yang berharga (hambar). Titus adalah seorang muda yang memiliki hati dalam melayani Tuhan sehingga dia memberikan hati sepenuhnya dalam melayani Tuhan. Tidak hanya itu, dia juga memberi diri sebagai uskup di Kreta pada waktu itu. Oleh karena dia memberi hatinya dalam melayani Tuhan.

Dengan demikian, para pelayan Tuhan sudah seharusnya memberi hati yang sungguhsungguh dalam melayani Tuhan. Sehingga orang-orang percaya maupun yang belum percaya diberkati dengan apa yang diperbuat. Oleh karena ada kesungguhan hati yang dimiliki seorang pelayan Tuhan yang memiliki integritas di dalam hidupnya baik secara pribadi maupun keluarga yang mendukung pelayanan. Jadi, milikilah kesungguhan hati di dalam melayani Tuhan karena selalu ada upah yang Tuhan berikan dalam setiap pelayanan yang dilakukan.

\section{Memiliki Pengajaran yang benar}

Hamba Tuhan memegang peranan yang sangat penting dalam pelayanan. Tidak cukup jika hanya bergantung pada pengetahuan dan teori dalam buku saja. Oleh karena itu, seorang Hamba Tuhan yang melayani di Gereja, hendaknya telah lahir baru, dan yang bertumbuh di 
dalam pengenalan akan Tuhan. Jika hamba Tuhan tidak mendasari hidupnya dengan Firman Tuhan, tidaklah mungkin dapat melayani dengan baik. Sebab jika seorang pelayan tidak memperhatikan kehidupan rohaninya dan tidak memiliki kerinduan untuk maju dalam iman rohaninya, maka tidak mungkin memiliki semangat untuk memperhatikan kehidupan rohani orang lain. Selain itu, pengajaran yang benar tentu hanya diperoleh lewat pengalaman hidup bersama dengan Tuhan, dan ketekunan melakukan kehendak Allah.

Seorang pelayan Tuhan seharusnya mengisi diri dengan pengetahuan Alkitab, itu sebabnya harus terlebih dahulu membekali dirinya dengan pengetahuan akan Firman Tuhan barulah dapat mengajarkannya. Sehingga apa yang disampaikan benar-benar sesuai dengan kehendak Allah. Dengan demikian, orang-orang yang dilayani dapat memahami apa yang disampaikan, dan dapat meneladani apa yang baik dilakukan oleh para pelayan Tuhan. Selain itu sebaiknya, pelayan Tuhan haruslah yang sudah menerima latihan dasar sebagai pelayan. Dengan demikian, kesuksesan pelayanan dimulai dari diri sendiri dan hubungan dengan Tuhan serta persiapan untuk melayani, sehingga apa yang dilakukan dalam pelayanan kepada jemaat-jemaat Tuhan dapat menerimanya dengan baik, dan semakin mengetahui kebenaran Allah dalam hidup mereka.

\section{Alkitab Adalah Firman Allah}

Alkitab adalah Firman Tuhan, oleh karena semua tulisan Alkitab adalah inspirasi Roh Kudus kepada penulisnya. Roh kudus membimbing para penulis, menulis apa yang Tuhan Firmankan. Oleh sebab itu Alkitab tidak pernah salah dalam naskah aslinya, sehingga Alkitab merupakan kebenaran Allah yang mutlak. ${ }^{61}$ Sebagai kebenaran mutlak, Alkitab wajib menjadi sumber pengajaran yang benar. Sudah seharusnya semua pengajaran didasarkan pada Alkitab yang berotoritas. Alkitab berotoritas karena Alkitab adalah wahyu Allah atau penyataan Allah yang ditulis bagi manusia.

Mengajari jemaat-jemaat Tuhan adalah tugas hamba Tuhan yang harus dijalankan sebagai wujud dari tanggungjawab kepada Tuhan. Alkitab menjadi dasar dan sumber bagi hamba Tuhan untuk mengajari jemaat-jemaat Tuhan. Ada banyak bahan atau teori-teori yang berbicara tentang bagaimana mendidik dan mengajar, bagaimanapun Alkitab harus menempati posisi atas semuanya itu. Manfaat dari Alkitab yaitu untuk mengajar, menyatakan kesalahan, untuk memperbaiki kelakuan dan untuk mendidik orang dalam kebenaran (2Tim. 3: 16). Dengan demikian, para pelayan Tuhan harus melandasi pelayanan dengan pengajaran yang benar yaitu Firman Tuhan.

\section{Memiliki Pengertian Yang Benar Akan Firman Tuhan}

Gembala ataupun Majelis-majelis harus menunjukkan bahwa satu-satunya jalan penebusan dosa ialah Yesus Kristus. Jemaat Tuhan harus mengerti bahwa Allahlah yang menjadi pusat dari berita Injil, jadi ajaran mengenai Yesus Kristus harus menjadi fokus utama dan rancangan dari semua pelajaran rohani yang harus disampaikan kepada jemaat Tuhan. Oleh sebab itu, harus ditanamkan pengajaran yang benar mengenai Frman Tuhan, jemaat Tuhan harus mengetahui bahwa Dia adalah Allah yang kekal seperti yang tertulis dalam Yohanes 1: 1-3, 14. "Pada mulanya adalah Firman; Firman itu bersama-sama dengan Allah, dan Firman itu adalah Allah....Segala sesuatu dijadikan oleh Dia dan tanpa Dia tidak ada suatu apapun yang telah terjadi dari segala yang telah dijadikan....". ${ }^{62}$

Dengan demikian, para pelayan Tuhan menyampaikan Firman Tuhan harus diberitakan dengan sebaik mungkin sehingga mencapai tujuan yang sesuai dengan kehendak Allah, yakni tujuan penyelamatan bagi setiap orang yang mendengar dan yang melakukan Firman itu. Dan Firman Tuhan harus menjawab pertanyaan dan berbicara kepada persoalan

\footnotetext{
${ }^{61}$ Douglas, Ensiklopedia Alkitab..., 391

${ }^{62}$ Yohanes 1:1-3, 14
} 
mereka, serta harus dapat menguatkan dan mengarahkan mereka untuk hidup sesuai dengan kehendak Tuhan.

\section{KESIMPULAN}

Karya keselamatan dan pemeliharaan Allah dalam kehidupan setiap orang percaya secara khusus para pelayan-pelayan Tuhan merupakan suatu anugerah yang luar biasa, oleh karena itu selayaknya setiap pelayan Tuhan bersyukur kepada Tuhan atas segala anugerahNya. Sehingga memberi diri untuk hidup melayani dan menyenangkan hati Tuhan. Namun dalam pelayanan para pelayan-pelayan Tuhan tidak terlepas dari problematika yang dapat membuat pelayanannya tidak berhasil. Menyikapi problematika para pelayan Tuhan dalam pelayanan, maka setiap pelayan Tuhan perlu memahami pentingnya integritas diri seorang pelayan Kristus dalam melayani yang sesungguhnya yaitu memuliakan nama Tuhan.

Pelayanan merupakan salah satu pekerjaan baik yang harus dikerjakan, dan hanya pelayan Tuhan yang telah mengalami lahir baru serta mendapatkan anugerah pengampunan dari Allah dan menyadari bahwa dirinya adalah ciptaan Allah yang berharga, yang layak melayani Tuhan. Sebab dengan pelayanan yang memiliki hubungan pribadi dengan Tuhan, memiliki kepribadian yang baik, menjadi saksi melalui sikap hidup dan memiliki prinsip yang benar dalam melayani Tuhan.

Pentingnya integritas pelayan Kristus menurut Titus 1: 6-9 dalam upaya peningkatan pelayanan gerejawi, oleh karena memberikan pengajaran yang sangat penting tentang integritas seorang pelayan. Oleh karena di dalamnya terkandung makna pelayanan yang sesungguhnya yang berkenan di hati Allah yaitu melayani dengan memberikan yang terbaik untuk Tuhan. Jika seorang pelayan melayani tidak memahami pentingnya integritas seorang pelayan yang sesungguhnya maka akan berdampak buruk bagi pelayanan yang ada. Seorang yang melayani Tuhan haruslah seorang yang sudah bertobat atau mengalami kelahiran baru. Pertobatan membuat para pelayan Tuhan melayani secara efektif dan memiliki tanggungjawab serta terbeban dalam melayani Tuhan dan Sesama.

Para pelayan Tuhan harus menyadari dan meyakini bahwa ia dipanggil oleh Allah, karena panggilan yang jelas membuat pelayanan para pelayan Kristus memiliki tujuan dalam pelayanan. Pemahaman yang benar akan panggilan membuat para pelayan Tuhan memiliki motivasi yang benar dalam pelayanan dan pelayanannya teruji dalam segala situasi, baik situasi suka, duka dan menyakitkan sekalipun.

Dengan demikian, para pelayan Kristus dalam pelayanannya harus memberikan yang terbaik untuk Tuhan, baik hubungan secara pribadi dengan Tuhan, memiliki kepribadian yang baik, menjadi saksi melalui sikap hidup dan memiliki prinsip yang benar dalam melayani Tuhan, maka peningkatan pelayanan gerejawi akan bertumbuh, gereja bertumbuh dan yang paling utama nama Tuhan dimuliakan. Dan melalui pentingnya integritas pelayan Kristus ini maka para pelayan-pelayan dapat menjadi teladan dan berkat bagi semua jemaat yang dilayani serta menjadi saksi bagi semua orang yang ada disekitar lingkungan yang mereka tinggali. 


\section{KEPUSTAKAAN}

Barker, Kenneth,

1985 The NIV Study Bible, Michigan: Zondervan Publishing House

Bergant, Dianne dan Robert J. Karris,

2002 Tafsir Alkitab PB, Yogyakarta: KANISIUS

Blaiklock, E. M.,

1981 Surat-surat Penggembalaan, Malang: Gandum Mas

Blaimeres Harry,

2003 The Post Christian Mind, Surabaya: Momentum

Brill, J. Wesley,

Dasar Yang Teguh, Bandung: Kalam Hidup

Budiman, R.,

1989 Surat-surat Pastoral, Jakarta: Gunung Mulia

Chamberlain, William D.,

1943 The Meaning of Repentence, Philadelphia: Westminster

Daun, Paulus,

2008 Kristen yang Bertumbuh, Manado: Yayasan Daun Family

Douglas J. D,

2008 Ensiklopedi Alkitab Masa Kini Jilid I, Jakarta: Yayasan Komunikasi Bina Kasih

Douglas, J. D,

2008 Ensiklopedi Alkitab Masa Kini Jilid II, Jakarta: Yayasan Komunikasi

Bina Kasih

Fances, Eddy,

2003 Mengenal dan Dikenal Allah Jakarta: Yasinta

Gordon, Bob,

$2000 \quad$ Motivasi Seorang Pemimpin, Jakarta: Nafiri Gabriel

Griffiths, Michael,

1975 Ambillah Aku Melayani Engkau, Jakarta: BPK Gunung Mulia

Hawkins, Joyce M.,

1999 Oxford-Erlangga Kamus Dwibahasa, Jakarta: Erlangga

Heath, W. Stanlay,

2005 Theologia Pendidikan Anak, Dasar Pelayanan Kepada Anak, Bandung:

Yayasan Kalam Hidup 
Hoekema, Anthony A.,

2001 Diselamatkan Oleh Anugerah, Surabaya: Momentum

Ismail, Andar, 1996 Selamat Melayani Tuhan, Jakarta: BPK Gunung Mulia,

Lukman, Ali,

1991

Kamus Besar Bahasa Indonesia, Jakarta: Balai Pustaka

Newman Jr, Barclay M.,

$1991 \quad$ Kamus Yunani-Indonesia, Jakarta: BPK Gunung Mulia

Packer, J. I.,

1992 Kristen Sejati Volume II, Jakarta: Lembaga Reformed Injili Indonesia

Poerwadarminta,

1997 Kamus Umum Bahasa Indonesia, Jakarta: Balai Pustaka

Prince, Derek,

1993 Bertobat dan Percaya, Jakarta: Yayasan Pekabaran Injil "IMMANUEL"

Prince, Derek,

1994 Iman yang Olehnya Kita Hidup, Jakarta: Yayasan Pekabaran Injil

"IMMANUEL"

Rim, Jeremia,

1995 Iman yang Hidup dan Berkuasa, Yokyakarta: Yayasan Andi

Saputra, U. T.,

2005 Beriman di Kancah Kehidupan, Bandung: Bina Media Informasi

Simorangkir, Ijois,

2012

Konsep yang Baik, Tanjung Enim: STTE

Sutanto, Hasan,

2003 Perjanjian Baru Interlinier dan Konkordansi Perjanjian Baru I, Jakarta:

LAI

Tan, John R.,

2006 Dinamika Pertumbuhan Iman Kristen, Jakarta: Yasinta

Tong Stephen,

$2001 \quad$ Kerajaan Allah, Gereja dan Pelayanan, Surabaya: Momentum

Tong, Stephen,

1992 Hidup Kristen yang Berubah, Jakarta: Lembaga Reformed Injili

Indonesia

Tulluan, Ola,

1999 Introduksi Perjanjian Baru, Batu: YPPII 
Warren, Rick,

2011

The Purpose Driven Life, Jawa Timur: Gandum Mas

Whitney, Donald S,

2001 Disiplin Rohani:10 Pilar Penopang Kehidupan Kristen, Bandung: Literatur Baptis

Wiersbe, Warren W.,

201010 Kekuatan Pelayanan yang Alkitabiah, Jakarta: Yayasan Andi,

Zodhiates, Spiros,

1977 The Hebrew-Greek Key Study Bible, La Habra: The Lockman

Foundation 